ppi $201502 Z U 4645$

Esta publicación científica en formato digital es continuidad de la revista impresa ISSN-Versión Impresa 0798-1406 / ISSN-Versión on line 2542-3185Depósito legal pp $197402 Z$ U34
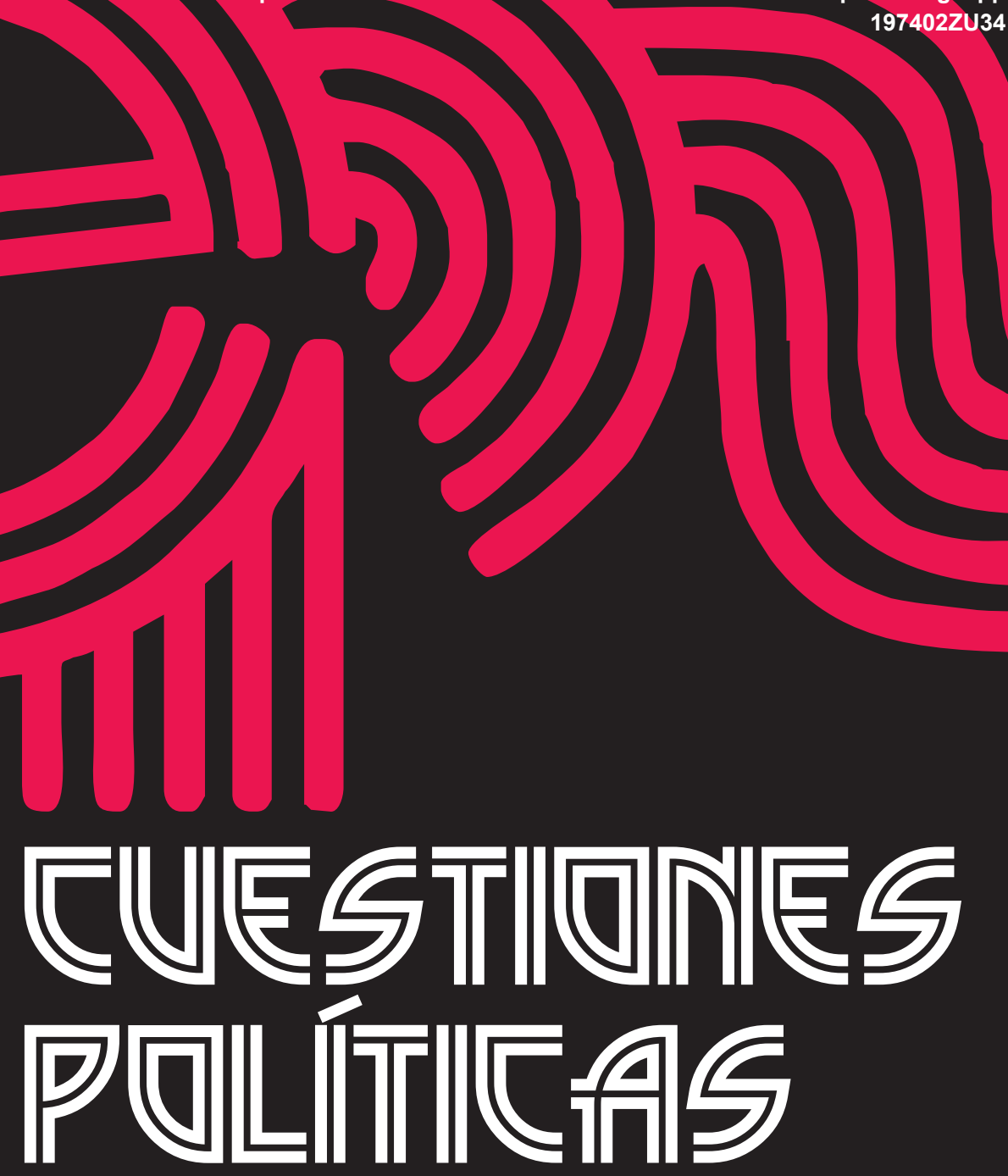

Instituto de Estudios Políticos y Derecho Público "Dr. Humberto J. La Roche" de la Facultad de Ciencias Jurídicas y Políticas de la Universidad del Zulia Maracaibo, Venezuela
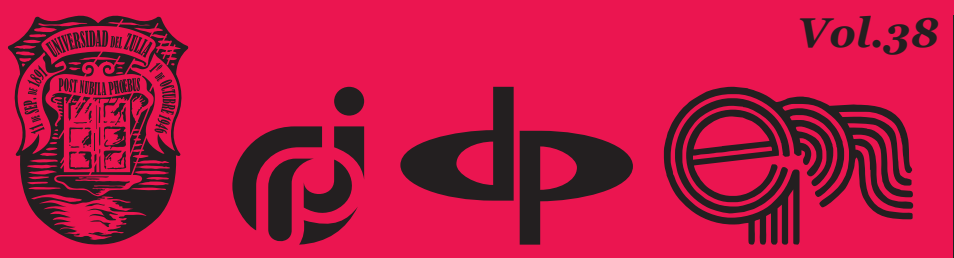

$N^{\circ}$ Especial 2da Parte 2020 


\title{
State regulation efficiency of food companies of Russia in sanction period
}

\author{
DOI: https://doi.org/10.46398/cuestpol.382e.31
}

\author{
Alexander Sergeevich Baleevskikh * \\ Oleg Ilyasovich Katlishin **
}

\begin{abstract}
The article is dedicated to the new political course of the Russian Federation, aimed at overcoming the economic blockade of the countries of Europe, as well as the United States. Effective management of food enterprises should take into account the new economic conditions for the functioning of the food economic subsector. In view of the crisis associated with the spread of coronavirus, falling oil prices, the ruble situation, the development of an economic course to adapt the Russian food industry becomes paramount. Therefore, the purpose of this article is a set of government measures to regulate the dairy food complex of the Russian Federation, both federally and regionally for the period 2008-2018. An analysis of the dynamics of milk industry indicators showed that the level of self-sufficiency for the period 2008-2018 was below the standard: 0.90. The study correlated the economics "import" and "self-sufficiency". Based on the data, it is concluded that the Russian Federation needs global innovation in the food industry mainly to the effective management of the
\end{abstract} agricultural dairy subsector.

Keywords: management of food companies; sanctions in Russia; dairy industry; dependence on imports; policy of modernization of the dairy industry.

* PhD in Economics, Head of Department of Commodity Research and Examination of Goods, Perm State Agro-Technological University named after Academician D.N. Pryanishnikov, Russia; PhD in Economics, Associate Professor of Department of Economics and Industrial Production Management, Perm National Research Polytechnic University, Russia. ORCID ID: https://orcid.org/oooo-00026050-1275. Email: tatamk11@rambler.ru

** PhD in Economics, Associate Professor of Department of Commodity Research and Examination of Goods, Perm State Agro-Technological University named after Academician D.N. Pryanishnikov, Russia; Associate Professor of Department of Economic Analysis and Statistics, Perm Institute, branch of REU named after G. V. Plekhanov, Russia. ORCID ID: https://orcid.org/oooo-00o3-2869-2312. Email: tatamk11@rambler.ru 


\section{Eficiencia de la regulación estatal de las compañías alimentarias de Rusia en el período de sanciones}

\section{Resumen}

El artículo está dedicado al nuevo curso político de la Federación de Rusia, destinado a superar el bloqueo económico de los países de Europa, así como de los Estados Unidos. La gestión eficaz de las empresas alimentarias debería llevarse a cabo teniendo en cuenta las nuevas condiciones económicas para el funcionamiento del subsector económico alimentario. En vista de la crisis económica asociada con la propagación del coronavirus, la caída de los precios del petróleo, la situación inestable del rublo, el desarrollo de un curso económico para adaptar la industria alimentaria rusa se vuelve primordial. Por lo tanto, el propósito de este artículo es analizar un conjunto de medidas gubernamentales para regular el complejo de alimentos lácteos de la Federación Rusa, tanto a nivel federal como regional para el período 2008-2018. Un análisis de la dinámica de los indicadores de la industria láctea mostró que el nivel de autosuficiencia para el período 2008-2018 estaba por debajo del estándar: 0,90. El estudio correlacionó los indicadores económicos «importación» y «autosuficiencia». Con base en los datos obtenidos, se concluye que la Federación de Rusia necesita innovación global en la industria alimentaria principalmente debido a la gestión efectiva del subsector lácteo de la agricultura.

Palabras claves: gestión de empresas alimentarias; período de sanciones en Rusia; industria láctea; dependencia de importaciones; política de modernización de la industria láctea.

\section{Introduction}

The aim of the research was to analyze a set of state measures to regulate the food dairy subcomplex of the Russian Federation both at the federal and regional levels for the period 2008-2018. The scientific hypothesis is based on the assumption that there is an inverse correlation between the indicators "import" and "self-sufficiency" in the sphere of consumption of products of the dairy agricultural subcomplex.

The modern food industry is forced to function in an unstable economy. On the one hand, there is a revolution in technology, and on the other, a dramatically changing political situation. Greatly influenced by all factors there are rapidly occurring changes. L. V. Ermolina notes that the introduction of innovative food management methods requires the 
continuous search for new, more effective management tools that ensure the successful adaptation of the enterprise to changing market conditions, as well as its ability to withstand competition, including international (Ermolina, 2015). A. S. Baleevskikh expresses the opinion that, under the influence of external changes, the improvement of management systems of Russian food companies turns into the problem of introducing a completely different management system that can be changed (Baleevskikh , 2016).

E. I. Afandeeva states that the basis of innovative management is the ability to adapt changes in external environment, the flexibility of management apparatus (Afandeeva , 2016). Innovative management should take into account the new economic conditions in which food companies are located. N. A. Kudrova emphasizes the fact that, after ten years of constant economic recovery and improving the well-being of the population, Russia faced serious economic and political problems of the global crisis, which made it necessary to revise import substitution strategies and strengthen coordination of state and regional policies for stable economic development of the country (Kudrova, 2015).

The modern confrontation with the United States, its allied countries and the reciprocal food embargo have led the development opportunities for our country's agri-food complex under conditions of accelerated import substitution. According to comments of U. G. Gusmanov, R. U. Gusmanov, E.V. Stovba, import substitution is becoming a difficult scientific direction, but also one of the main trends in development of Russian economy, which will strengthen, stimulate and develop our own production of products (Gusmanov et al., 2016).

President of the Russian Fedeation V. V. Putin in his speech in May 2014 emphasized: "Russia will pursue an active policy of import substitution" in accordance with WTO standards and obligations to partners in Eurasian Economic Union. The President also noted: "I consider it necessary to quickly analyze the possibilities of competitive import substitution in industry and agriculture..." (Roscongress Foundation, in https://roscongress.org/ events/pmef-2014/sessions/, 2014). In his message V. V. Putin has set the task of fully providing the country with basic domestic food supplies over the next 4-5 years.

The economic crisis of 2019-2020, associated with coronavirus, exacerbated the unstable economy of the Russian Federation. Against the background of reduction in cooperation with China, the EU extended its sanctions policy towards Russia until the end of January 2020 (Interfax, https://www.interfax.ru/russia/666875, 2020). Military and investment cooperation between the US and the EU with Russia has suspended, export and import of weapons and defense industry products have limited. Russian state-owned banks and oil industry are also subject to sanctions. Russia's answer in this situation is food embargo introduction. Achieving real 
economic growth the creation of new industries requires. The importance and significance of developing and implementing an import substitution policy amid the ongoing geopolitical crisis and economic sanctions of the leading world powers.

\section{Literature review}

The literature devoted to the problem of effective management of food enterprises of the Russian Federation in the context of import substitution in the period 2008-2018 is represented by the works of I. F. Sukhanova, M. Yu. Lyavina, R. Grabovsky, N. N Pronina, D.I. Oganezova, O. V. Usenkova, S. Mukherjee, M. M. Galeev, E. M. Radosteva, E. V. Bartova, G. N. Ivanova, Yu. V. Vertakova, V. A. Plotnikov, T. Yu. Annonchenko, T. E. Kutyaeva, N. M. Shpak, E. A. Stepanov (Sukhanova et al., 2014; Grabovski 1994; Pronina et al., 2015; Mukerji 2012; Galeev et al., 2015; Ivanova 2011; Vertakova et al, 2014; Annonchenko et al., 2015; Kutyaeva 2014; Shpak 2015; Stepanov 2015; Kiseleva et al., 2019; Pinkovestkaia et al., 2019a; Pinkovestkaia et al., 2020).

In general, there are two scientific approaches to the issue of implementing the import substitution policy of food industry within the Russian Federation: 1. the special economic strategy for the development of food industry; 2 . the national strategy for innovation of food economic sub-sector and defense security.

A number of scientists, such as I. F. Sukhanova, M. Yu. Lyavina, R. Grabowski, N.N. Pronina, D. I. Oganezova, O. V. Usenkova, S. Mukherjee are adjacent to the scientific direction, within the framework of which the state policy on the development of the food industry is carried out (Sukhanova et al, 2014; Grabovski 1994; Pronina et al, 2015; Mukerji 2012). I. F. Sukhanova, M. Yu. Lyavina believe that the economic policy of strengthening food economic sub-sector is revealed through government measures aimed at supporting domestic agricultural producers, as well as food enterprises (Sukhanova et. al., 2014). R. Grabowski, N. N. Pronina, D. I. Oganezova, O.V. Usenkova express the opinion that import substitution of food products is a long-term state strategy for rationalizing and optimizing imports of agricultural products and a mechanism to stimulate competitiveness in domestic market (Grabowski 1994; Pronina et al, 2015). S. Mukherjee suggests that the state strategy for import substitution of food industry should focus on the problem of training qualified personnel, strengthening the country's intellectual and economic power (Mukerji 2012). 
Alexander Sergeevich Baleevskikh y Oleg Ilyasovich Katlishin
$400 \quad$ State regulation efficiency of food companies of Russia in sanction period

The second scientific approach related to the development of national strategy, including the innovation of food economic sub-sector and strengthening of defense security of the Russian Federation is shared by M. M. Galeev, E. M. Radosteva, E. V. Bartova, G. N. Ivanova, Yu. V. Vertakova, V. A. Plotnikov, T. Yu. Annonchenko, A. I. Novitskaya, T. E. Kutyaeva, N. M. Shpak, E. A. Stepanov (Galeev et al, 2015; Ivanova 2011; Vertakova et al, 2014; Annonchenko et al, 2015; Kutyaeva 2014; Shpak 2015; Stepanov 2015).

Researchers M. M. Galeev, E. M. Radosteva, E. V. Bartova, G. N. Ivanova, adhering to the strategy of national development of food economic sub-sector and defense security of Russia, nevertheless, note that the import of food sub-complex for the period 2008-2018 has been increased (Galeev, 2015; Ivanova, 2011). A number of scientists Yu. V. Vertakova, V. A. Plotnikov, T. Yu. Annonchenko, A. I. Novitskaya, T. E. Kutyaeva are inclined towards the political course of national economic and defense security, which is based on measures aimed at restructuring the economic development model and updating food technology. In particular, N. M. Shpak and E. A. Stepanov express the view that technical modernization may become a decisive factor in production of the dairy sub-sector, as a result of which there will be an increase in export of dairy products and a decrease in export of dairy products from Brazil and the Republic of Belarus (Shpak 2015; Stepanov 2015).

\section{Materials and methods}

The aim of the research was to analyze a set of state measures to regulate the food dairy subcomplex of the Russian Federation both at the federal and regional levels for the period 2008-2018. The scientific hypothesis is based on the assumption that there is an inverse correlation between the indicators "import" and "self-sufficiency" in the sphere of consumption of products of the dairy agricultural subcomplex. To achieve the aforementioned goal, the following methods of economic research were used: monographic method, abstract logical method, analysis and synthesis method, method for comparing economic indicators, economic-static method (method of economic correlation analysis).

The following formula calculates the value of Russia's self-sufficiency in a particular type of product (\%):

$100 \%$,

where the numerator is domestic production in the national economy (P) without export (E); in the denominator is the total receipt of products, both domestic and imported (I). 
Import substitution value for the period $t$ is equal to:

$\Delta \mathrm{t}=\alpha \mathrm{t}-\alpha \mathrm{O}$.

The value of import dependence is calculated by the formula:

$\gamma=100 \%$.

\section{Results}

In recent years, meat (15-16\% of total food imports), fruits (14.8\%), vegetables $(6.7 \%)$, as well as milk (10\%) and alcohol (8\%) products have occupied a leading position in sustainable structure of food imports (Federal Customs Service in: http://customs.ru/, 2020).

In the food sector, threshold (minimum allowable) values of the share of domestic products in domestic market have been introduced, which ensure food security for milk production industry - 90\%. (Food Security Doctrine of the Russian Federation. Approved by presidential decree № 120, April 30, 2010, 2020).

Let us analyze the indicators of import dependence and import substitution of the country for 10 years. Table 1 presents the resources and use of milk and milk products.

\begin{tabular}{|c|c|c|c|c|}
\hline Year & \multicolumn{4}{|c|}{ I. RESOURCES } \\
\hline & $\begin{array}{c}\text { Stocks at the } \\
\text { beginning of the } \\
\text { year, thousand } \\
\text { tons }\end{array}$ & $\begin{array}{c}\text { Production (gross } \\
\text { harvest in clean } \\
\text { weight), thousand } \\
\text { tons }\end{array}$ & $\begin{array}{c}\text { Import, } \\
\text { thousand } \\
\text { tons }\end{array}$ & $\begin{array}{c}\text { Total } \\
\text { resources, } \\
\text { thousand tons }\end{array}$ \\
\hline 2008 & 1693 & 30826 & 7115 & 39634 \\
\hline 2009 & 1777 & 31097 & 7293 & 40167 \\
\hline 2010 & 1870 & 31988 & 7134 & 40992 \\
\hline 2011 & 1926 & 32363 & 7315 & 41604 \\
\hline 2012 & 2097 & 32570 & 7005 & 41672 \\
\hline 2013 & 1857 & 31847 & 8159 & 41863 \\
\hline 2014 & 1866 & 31646 & 7938 & 41450 \\
\hline 2015 & 1995 & 31756 & 8516 & 42267 \\
\hline 2016 & 2032 & 30529 & 9445 & 42006 \\
\hline 2017 & 1982 & 30791 & 9155 & 41928 \\
\hline
\end{tabular}


Alexander Sergeevich Baleevskikh y Oleg Ilyasovich Katlishin

\begin{tabular}{|c|c|c|c|c|}
\hline 2018 & 2120 & 30781 & 7011 & 39912 \\
\hline \multicolumn{5}{|c|}{ II. USE } \\
\hline & $\begin{array}{l}\text { Consum-ption } \\
\text { using the } \\
\text { production, } \\
\text { thousand tons }\end{array}$ & $\begin{array}{l}\text { Loss, thousand } \\
\text { tons }\end{array}$ & $\begin{array}{l}\text { Export, } \\
\text { thousand } \\
\text { tons }\end{array}$ & $\begin{array}{l}\text { Stocks at the } \\
\text { end of the } \\
\text { reporting } \\
\text { period, } \\
\text { thousand tons }\end{array}$ \\
\hline 2008 & 4097 & 493 & 33250 & 1777 \\
\hline 2009 & 4067 & 532 & 33687 & 1860 \\
\hline 2010 & 4168 & 582 & 34295 & 1926 \\
\hline 2011 & 4308 & 612 & 34566 & 2097 \\
\hline 2012 & 4372 & 520 & 34900 & 1857 \\
\hline 2013 & 4271 & 460 & 35237 & 1866 \\
\hline 2014 & 3622 & 614 & 35189 & 1995 \\
\hline 2015 & 3919 & 645 & 35642 & 2032 \\
\hline 2016 & 3742 & 628 & 35633 & 1971 \\
\hline 2017 & 3482 & 629 & 35661 & 2120 \\
\hline 2018 & 3079 & 602 & 34348 & 1861 \\
\hline \multicolumn{5}{|c|}{ III. INDICATORS } \\
\hline & Selfsufficiency & $\begin{array}{c}\text { Import } \\
\text { substitution }\end{array}$ & \multicolumn{2}{|c|}{ Import dependence } \\
\hline 2008 & 0,8096 & & \multicolumn{2}{|c|}{0,1904} \\
\hline 2009 & 0,8069 & $-0,03$ & \multicolumn{2}{|c|}{0,1931} \\
\hline 2010 & 0,8146 & 0,005 & \multicolumn{2}{|c|}{0,1854} \\
\hline 2011 & 0,8119 & 0,002 & \multicolumn{2}{|c|}{0,1881} \\
\hline 2012 & 0,8217 & 0,012 & \multicolumn{2}{|c|}{0,1783} \\
\hline 2013 & 0,7936 & $-0,016$ & \multicolumn{2}{|c|}{0,2064} \\
\hline 2014 & 0,7956 & $-0,014$ & \multicolumn{2}{|c|}{0,2044} \\
\hline 2015 & 0,7849 & $-0,025$ & \multicolumn{2}{|c|}{0,2151} \\
\hline 2016 & 0,7603 & $-0,049$ & \multicolumn{2}{|c|}{0,2397} \\
\hline 2017 & 0,7663 & $-0,043$ & \multicolumn{2}{|c|}{0,2337} \\
\hline 2018 & 0,8128 & 0,003 & \multicolumn{2}{|c|}{0,1872} \\
\hline
\end{tabular}

Table 1. Resources and use of milk and dairy products from 2008 to 2018. Own elaboration. 
All indicators of self-sufficiency are less than the threshold indicator of 0.90. So the requirements of the doctrine of food security are not fulfilled. Therefore, the milk processing industry can be attributed to the importdependent food industry.

We will conduct additional studies of the indicator of self-sufficiency in order to identify the relationship between the data presented in Table 2. For this, we will be using the statistical control methods, namely, the scatter chart proposed by A. Cohen, T. Tiplica, A. Kobi, J. Henn, K. Meindl (Cohen et al, 2016; Henn et al, Meindl, 2015). Correlation study indicators "production" and "import" are presented in Figure 1.

The diagram allows us to put forward a hypothesis that there is an inverse correlation dependence between the "import" and "production" indicators; we will test this hypothesis using the median method. To do this, we will draw the horizontal and vertical medians and determine the number of points in each quarter.

$$
\begin{aligned}
& \mathrm{n}(+)=\mathrm{n} 1+\mathrm{n} 3=2+3=5, \\
& \mathrm{n}(-)=\mathrm{n} 2+\mathrm{n} 4=2+2=4, \\
& \mathrm{n}^{\prime}=\mathrm{n}(+)+\mathrm{n}(-)=5+4=9 .
\end{aligned}
$$

Since one point is on the media, $\mathrm{n}$ ' $=9$ is not equal to $\mathrm{n}=11$.

\begin{tabular}{|c|c|c|c|c|c|c|c|c|c|c|c|c|}
\hline \multicolumn{2}{|r|}{$n^{\prime}$} & 8 & 9 & 10 & 11 & 12 & 13 & 14 & 15 & 16 & 17 & 18 \\
\hline \multirow[t]{2}{*}{$\alpha$} & 0,01 & O & O & 0 & 0 & 1 & 1 & 1 & 2 & 2 & 2 & 3 \\
\hline & 0,05 & $\mathrm{O}$ & 1 & 1 & 1 & 2 & 2 & 2 & 3 & 3 & 4 & 4 \\
\hline
\end{tabular}

We set the risk coefficient $\alpha=0.05$ and determine the code value using statistical Table 2.

Table 2. The dependence of the code values of risk factor and number of points that didn't fall on the median. Own elaboration. 
Alexander Sergeevich Baleevskikh y Oleg Ilyasovich Katlishin

404

State regulation efficiency of food companies of Russia in sanction period

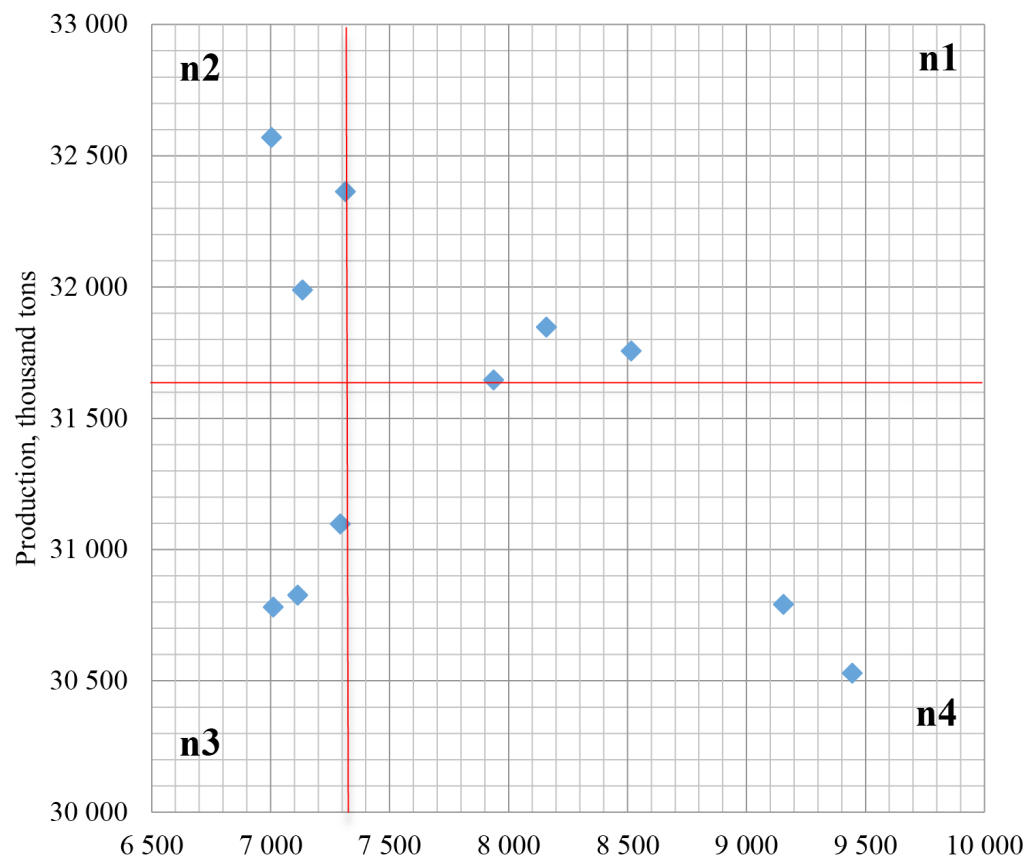

Import, thousand tons

Figure 1. The scatter plot, reflecting the dependence of the production and import of dairy products. Own elaboration

The scatter plot in Figure 1 showed that the inverse correlation does not occur with a risk factor of 0.05 . The median method quantitatively confirms or refutes the relationship between a pair of presented indicators. To confirm the dependence, it is necessary that the inequality holds: the smaller of the numbers $n(+)$ and $n(-)$ is less than the code value or equal. In this case, the smallest of the numbers $n(+)$ and $n(-)$ is $n(-)=4$, and it is larger than the code value $=1$.

\section{Discussion}

From the point of view of economic theory, import substitution is the reduction or termination of foreign deliveries of goods through the growth of domestic production. However, this is not complete, far from 
comprehensive definition of import substitution as economic category. In the views of I. F. Sukhanova, M. Yu. Lyavina, import substitution is a special type of state economic strategy and industrial policy aimed at protecting domestic producers and providing the country's population with all necessary consumer goods, food and agricultural raw materials by replacing imported goods with national production (Sukhanova et al., 2014).

The economic development of Russia is influenced by negative factors, among which one can single out a high probability of stagnation, a drop in oil prices, and the devaluation of ruble. Today, the solution of the problems of advanced import substitution is becoming one of the main tasks of federal and regional development policies.

R. Grabowski notes that import substitution is a scientifically based longterm government strategy to rationalize and optimize the import of goods and services by supporting domestic producers and indirectly regulating imports with protectionist instruments (Grabowski, 1994) . The import substitution policy is based on creating an enabling environment for the growth of national industry. According to N. N. Pronina, D. I. Oganezova, O. V. Usenkova, the policy of import substitution involves the creation of artificial incentives for the development of certain sectors of domestic industry in order to increase their competitiveness in domestic market (Pronina et al, 2015). Activities to reduce the import intensity is important and relevant for modern Russia.

S. Mukherjee emphasizes that import of products is mostly associated with the lack of sufficient raw materials and necessary stocks, as well as the lack of training of qualified personnel, especially through the development of particular economic stage (Mukherjee, 2012). Issues of import substitution become especially relevant during periods of economic crisis (perestroika, various recessions, sanctions). At the same time, import of goods and services plays a positive role, allowing to accelerate intellectual and economic growth, overcoming economic lag, creating tactical and strategic reserves and stocks, mitigating delays in development of individual industries, enterprises and regions, establishing productive and useful relationships with other companies and countries.

Following economic growth of Russia over past 10 years, one can notice a strong growth in product imports. Gross domestic product increased 3.5 times from 21.6 trillion rubles in 2008 to 76.4 trillion rubles in 2018. At the same time, imports are growing 2.6 times from 4.9 trillion rubles in 2008 to 12.8 trillion rubles in 2018. Import dependence is gradually decreasing, but still makes up a high $16.8 \%$ of gross domestic product. Researchers M. M. Galeev, E. M. Radosteva, E. V. Bartova, and G. N. Ivanova state that, in terms of agricultural and food sectors of economy, agricultural machinery, and modern technologies, the import of goods remains significant (Galeev et al, 2015; Ivanova, 2011). 
For many types of innovative products and components, Russia will not be able to completely avoid import dependence in the context of globalization. It is necessary to ensure for key sectors of the economy the self-sufficiency and independence of their functioning from the external environment within the framework of implementation the national strategy of economic and defense security. Therefore, in the opinion of Yu. V. Vertakova and V. A. Plotnikov, the policy of restructuring the model of economic development due to the transition to importsubstituting production and advanced technologies in strategically important sectors is especially important for Russia today (Vertanova et al, 2014). The dairy industry is one of those industries.

T. Yu. Annonchenko, A. I. Novitskaya indicate that as a result of solving the problems of modernizing production and increasing capacity for the period 2020, an increase in production of whole milk products is planned up to 13.5 million tons, butter - up to 280 thousand tons (Annonchenko et al, 2015). According to the International Dairy Federation (IDF), in 2011, 749 million tons of milk were produced in the world, including 621 million tons of cow's milk. The largest milk producers are the EU countries (152 million tons), the USA (89 million tons), India ( 57 million tons), China (37 million tons), Brazil (33 million tons), Russia (32 million tons). T. E. Kutyaeva notes that the countries of European Union, the USA, India, China, Brazil, Russia provide $2 / 3$ of total world milk production (Kutyaeva, 2014).

Russia is considered one of the world's leading importers of butter and cheese. In order to overcome stagnation in the sub-industry and reduce dependence on imports of dairy products, it is necessary to create conditions that ensure a stable and long-term increase in domestic production of raw milk. According to N. M. Shpak, the main factor in increasing milk production is technical modernization (Shpak, 2015). E. A. Stepanov considers it is necessary to emphasize that Russia compensates for the shortage of dairy products consumption mainly by imports from Brazil and the Republic of Belarus (Stepanov, 2015).

\section{Conclusions}

The performed calculations allow us to draw several conclusions. According to the median method, in order to confirm the relationship between a pair of presented indicators, it is necessary that the inequality holds: the smaller of the numbers $n(+)$ and $n(-)$ the code value is less or equal. In this case, the smaller numbers $n(+)$ and $n(-)$, the larger the code value, which means that the inverse correlation does not occur with a risk coefficient of 0.05 . This means that this conclusion is true with a probability of $95 \%$. 
The issue of import substitution in food industry is highlighted by actively changing foreign policy and statements of the country's top officials. The threshold (minimum acceptable) indicator of milk at the level of $90 \%$ in domestic market, ensuring food security, was established by the Food Security Doctrine of the Russian Federation (ConsultantPlus, in http:// www.consultant.ru/document/cons_doc_LAW_96953/,2020). The selfsufficiency indicator for 2018 is 0.8128 , which is less than the threshold indicator of 0.90 . This suggests that the level of self-sufficiency does not meet the requirements of food security doctrine regarding the country's needs for milk and dairy products due to its own production. We emphasize that in 2012 the industry has reached its maximum performance - 0.8217, which is more than $10 \%$. The self-sufficiency indicator in Russia was below the standard (0.90) from 2008 to 2018.

A study of indicators "production" and "import" showed that there is no correlation between them, that is, an increase or decrease in own production does not affect the amount of imported dairy products. The number of imported products does not depend on the volume of domestic production, but has influenced by other external factors. Milk market situation in the Russian Federation and dairy products as a whole does not allow predicting a decrease in import dependence. Dependence from imports is consistently high and fluctuates around 0.20 over the past 10 years. The self-sufficiency of country's population with milk and dairy products needs additional reforms.

\section{Bibliographic References}

AFANDEEVA, Elvira Irekovna. 2016. “Management of innovative development of enterprises as the basis for formation the competitiveness of the economy". In: Journal of Science and Creativity. Vol. 3, No. 3, pp. 32-39.

ANNONCHENKO, Tatyana Yurievna; NOVITSKAYA, Alexandra Igorevna. 2015. "Dynamics and trends of development of food industry in modern conditions of Russia". In: Journal of Economic Regulation. Vol. 6, No. 1, pp. 21-27.

BALEEVSKIKH, Alexander Sergeevich. 2016. "Management of industrial enterprise in conditions of economic instability". In: Problems of modern Economics. Vol. 1, No. 57, pp. 68-71.

COHEN, Achraf; TIPLICA, Teodor; KOBI, Abdessamad. 2016. "Design of experiments and statistical process control using wavelets analysis". In: Control Engineering Practice. Vol. 49, pp. 129-138. 
Alexander Sergeevich Baleevskikh y Oleg Ilyasovich Katlishin
408 State regulation efficiency of food companies of Russia in sanction period

CONSULTANTPLUS. 2020. The food Security Doctrine of the Russian Federation. Approved by decree No. 120 of the president from 30.04.2010. In: Consultant Plus. Available online. In: http://www. consultant.ru/document/cons_doc_LAW_96953/. Consultation date: 12/03/2020.

ERMOLINA, Lilia Valerievna. 2015. "Process management as an innovative approach to the management of modern enterprises". In: Modern problems of science and education. Vol. 01, No.1, pp. 535-543.

FEDERAL CUSTOMS SERVICE. 2020. "Official site of the Federal customs service of Russia". In: Federal Customs Service. Available online. In: http://customs.ru/. Consultation date: 12/03/2020.

GALEEV, Marat Mirsayafovich; RADOSTEVA, Elvira Mazitovna; BARTOVA, Elena Valentinovna. 2015. "The possibilities of import substitution in food security of Russia”. In: Science Studies. Tom, 7, No. 3, pp. 1-9.

GRABOWSKI, Richard. 1994. "Import substitution, export promotion and the state in economic development". In: The Journal of Developing Areas. Vol. 28, No. 4, pp. 535-554.

GUSMANOV, Uzbek Gusmanovich; GUSMANOV, Rasul Uzbekovich; STOVBA, Evgeny Vladimirovich 2016. "Ensuring food security in region in terms of import (in example of Republic Bashkortostan)”. In: Far East agrarian bulletin. Vol. 3, No. 39, pp. 101-108.

HENN, Julian; MEINDL, Kathrin. 2015. "Statistical tests against systematic errors in data sets based on equality of residual means and variances from control samples: theory and applications". In: Acta Crystallographica Section A: Foundations and Advances. No. 71, pp. 203-211.

INTERFAX. 2020. "EU sectoral sanctions against Russia extended until January 31, 2020”. In: Interfax. Available online. In: https://www.interfax.ru/ russia/666875. Consultation date: 12/04/2020.

IVANOVA, Galina Nikolaevna. 2011. "International standards against the unstable economy". In: Standards and quality. No. 11, pp. 72-74.

KUDROVA, Nadezhda Anatolyevna. 2015. "Stimulating regional development policy of modern Russia based on the concept of import substitution". In: Socio-economic phenomena and processes. Vol. 10, No. 2, pp. 46-51.

KUTYAEVA, Tatyana Evgenyevna. 2014. "Modern state of the dairy industry in Russia”. In: Bulletin of NGIEI. Vol. 9, No. 40, pp. 76-81. 
MUKHERJEE, Soumyatanu. 2012. "Revisiting the debate over importsubstituting versus export-led industrialization". In: Trade and development review. Vol. 5, No. 1, pp. 64-76.

PINKOVETSKAIA, Iuliia; ARBELÁEZ CAMPILLO, Diego Felipe; ROJAS BAHAMÓN, Magda Julissa; GROMOVA, Tatiana; NIKITINA, Irina 2019. "Female entrepreneurship development in the Russian Federation". In: Amazonia Investiga. Vol. 8, No. 18, pp. 111-118.

PINKOVETSKAIA, Iuliia; LYUBOVTSEVA, Elena; ARBELÁEZ-CAMPILLO, Diego Felipe; ROJAS-BAHAMÓN, Magda Julissa. 2020. "Small and medium enterprises in Russia and other countries". In: Amazonia Investiga. Vol. 9, No. 25, pp. 99-106.

PRONINA, Natalia Nikolaevna; OGANEZOVA, Diana Igorevna; USENKOVA, Olesya Valerievna 2015. "The reality of import substitution in Russia". In: Proceedings of Penza state University. No. 3 (11), pp. 58-62.

ROSCONGRESS FOUNDATION. 2014. Speech by V.V. Putin at the plenary meeting of the 18th St. Petersburg International Economic Forum. In: Roscongress Foundation. Available online. In: https://roscongress.org/ events/pmef-2014/sessions/. Consultation date: 12/04/2020.

SHPAK, Nina Mikhailovna. 2015. "Features of reproductive process in dairy cattle breeding in Krasnodar Krai”. In: Polythematic network electronic scientific journal of Kuban State Agrarian University. No. 110, pp. 1-19.

STEPANOV, Evgeny Alexandrovich. 2015. "Features of dynamics of external trade of food products in Russia". In: Proceedings of Chelyabinsk State University. Vol. 8, No. 36, pp. 79-91.

SUKHANOVA, Irina. Fedorovna; LYAVINA, Mariya Yuryevna. 2014. "Import substitution as a factor of regional economic growth". In: Proceednigs of Volgograd State University. Series 3: Economics. Ecology. No. 5, pp. 27-35.

VERTAKOVA, Yulia Vladimirovna; PLOTNIKOV, Vladimir Alexandrovich. 2014. "Import substitution: a theoretical framework and prospects of implementation in Russia”. In: Economics and management. No. 11 pp. 11-47. 

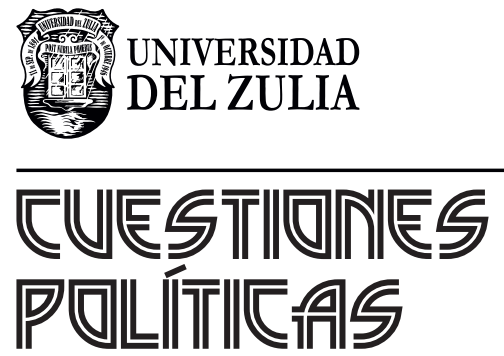

Vol.38 NEspecial

Esta revista fue editada en formato digital y publicada en diciembre de 2020, por el Fondo Editorial Serbiluz, Universidad del Zulia. Maracaibo-Venezuela 